\title{
最古の目録『デンカルマ』に録載された ティベット訳『法華経』の原本について
}

\section{岩 松 浅 夫}

1. はじめに ティベット（以下, “Tib.”と略記することにする）語に訳された仏教 の経典類の最初でまた現存最古の目録は『[目録]デンカルマ』11)で，そのような ことから同書は経典の訳出年代の新古を判定・判断する際の重要な基準〔の一〕 とされているが, 近時筆者は別のある経についてそのことを確かめているときに 偶まそこに『法華経』（Saddharmapundarika-sūtra. Tib. = Dam paii chos pad ma dkar po）が載 されていることを目にし，興味本位的に同経に関する記事を調べてみたところ が，そこには非常に重要な問題が蔵されていることに気が付いた，そこで，ここ ではその筆者が気付いた事柄等について述べてみることにしたい.

2.『デンカルマ目録』の記事とその問題点 その本題に入る前に, 該『目録』 の『法華経』に関する記事を揭げれば次の如くになるであろう²).

[79] 'Phags pa dam pa'i chos padma dkar po $\|(\mathrm{P} \|=\mid)$ shlo ka sum stong dgu brgya ste ( $\mathrm{P}$ adds $\mid)$ bam po bcu gsum $\mid$ (D [jo] 296b $\sim 297 \mathrm{a}^{1}, \mathrm{P}$ [cho] 355b ${ }^{3}$ [vol. 145, 143-3-3]).

すなわち，ここには経題と共にその分量が「シュロカ」(shlo ka) と「バンポ」 (bam po. 以下, “bp” と略) という2つの量目で示されて, 前者では“3900,”また後者 は“13”にそれぞれなるとされている，因みに言えば，前者の「シュロカ」は一 偈が 1 行 16 音節の 2 連から成るというサンスクリット（以下, “Skt.” と略記）の詩で は最もよく知られ多用もされている韻律の一つの śloka（以下, 前記の “shlo ka” の場 合も含めて “s”” と略）に由来するもので，ここでもその śl と同様に“32”の音〔節〕 数を表すものと考えてよいであろう。一方，後者の bp はインドよりはむしろ中 国で言う「巻」に相当し対応するもので，またその両者の関係に関しては，上の 言表からも知られるように 1 bp は300 ślに相当し，更に言えば “300 śl”を一括り にしたその量目〔の称呼〕が “bp”と解してもよいように筆者には思われるが如 何であろうが3. では，その“3900 śl”或いは“13 bp”の実際の分量はどれくらい 
になるのかと言えば，それについては現行の西蔵大蔵経のカンギュルに所収のも のを基にして言えば，例えばデルゲ版（以下，“D”と略）では“ja”の秩の $1 \mathrm{~b}^{1} \sim$ $180 \mathrm{~b}^{7}$ の各葉 (folio) が『法華経』とされているので葉の枚数では 180 枚, また面数 は359面で, 同様に北京版 (同, “P”) は“chu”秩の $1 \mathrm{~b}^{1} \sim 205 \mathrm{a}^{5}$ の $205^{5}$ 枚, 面数は $407^{5}$ 面にそれぞれなるということになろう ${ }^{4)}$.

と，このようにここ迄は特に問題や疑問に思われるようなことは何もない一 正確には，ないように見える——のであるが，問題は実はこの後に存するという ことになろう．そこで，その点について少し説明することにすれば，実は該『デ ンカルマ目録』には分量が同じ “3900 śl, 13 bp” とされるものがこの『法華経』以 外にも幾つか載されていて，ということで念のためにそれらの実際の分量を同様 に対応する〔と考えられる〕カンギュル所収本に当って調べ確認してみると, 先 に記した『法華経』のそれとは必ずしも一致しないだけでなく, それどころか非 常に大きな懸隔を示すものも存する——それも, 一つだけではなく複数で——と いうことである，具体的には，例えば [80］の『涅槃経』5) では D が2994面で $\mathrm{P}$ は311面, また [81]の『[大方等] 日蔵経』は D は $308^{1}$ 面で $\mathrm{P}$ は $322^{2}$ 面の如くそ れぞれなっていて, 試みにそれらと『法華経』の分量を比べて見ると, 前者の 『涅槃経』はD では〔359 $\div 300 \doteqdot 1.197^{6)}$ から〕約 $20 \%$ で $\mathrm{P}$ は〔同じく $408 \div 311 \doteqdot$

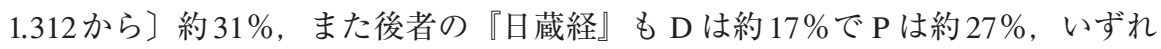
も『法華経』の方が多くなっているというわけである7).

尤も，この “3900 śl” や“13 bp”と言うときの“3900”や“13”の数值に関しては, 必ずしもそのまま通りということではなくてある程度の幅を持ってのものと解す べきかもしれない，そこで，その言わば「摇れの幅」(基準值からの〔想定される〕 ズレの許容範囲）は一体どの程度になるのかということを少し考えてみると, 先ず 後者の “bp” は〔整数の〕1段刻みになっていて，ただしその繰上げ法が不明なの でそれによって変ることにはなるが, ここでは仮に「四捨五入」によってなされ るとすれば該 “ 13 bp” はその表す範囲を x で表せば $12.5 \leqq \mathrm{x}<13.5$ (bp）の間で，ま た中心值からのズレの割合は $[0.5 \div 13 \doteqdot 0.038$ から 約 $4 \%$, もし仮に両極即ち最 小值と最大值を取れば両者の開きは2倍になるのでその割合も 2 倍の約 $8 \%$ にな るが，いずれにしても $8 \%$ 程度と見てよいであろう。一方，前者の “s”” に関して は, 数值は 300 刻みでただ後者の 1 bp を 300 ślに置換えただけなので割合自体は 変らずに，ただ “3900 śl”だけが同様にその表す範囲を y で表せば $3750 \leqq y<4050$ (śl）の如くなるということになろう。 
3. テキストの改変とそれを証明 (又は, 傍証) する資料について いずれに しても，このように実際の分量を該『法華経』とそれ以外の『涅槃経』や『日蔵 経』と比べて見ると，両者の間には〔もしそれが同じものを表すとすれば〕想定 される許容範囲を遥かに大きく超えたズレ（相違）が存する一一そのことが知ら れる—ことになるが，もしそうとすればそのことは一体どのように解し捉えた らよいのであろうか．それに対する対応の仕方は人によって様々あるであろう が，筆者は，一つには後者の『涅槃経』と『日蔵経』は実際の分量も略ぼ同じに なっている ${ }^{8)}$ ということと, またもう一つは後者の前の方の『涅槃経』は断片的 にであるが残された Skt.の写本からその分量が “3900 śl” に極めて! 近い「3894 偈」と算定されている ${ }^{9)}$ という2つのことから，該『デンカルマ目録』の記事は 後者の『涅槃経』や『日蔵経』の方が正しくて，したがって前者の『法華経』は 後世の改変（付加増広）によってかくなったと解するのが妥当と考える，という ことになろう。

では，もしそうとすればそのことを直接証明し，或いはそうでなくても傍証は するようなものは何か存するのであろうか，その点に関しては，筆者は必ずしも なくはない，と言うよりもむしろ積極的に存すると答えるということになろう． ではそれはどのようなものかと言えば，一つは現行の Tib. 訳本の調巻法と言う か各巻毎の分量の有り様ということで，具体的にはそれらつまり各巻の分量は

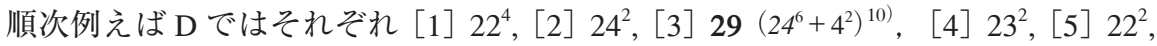

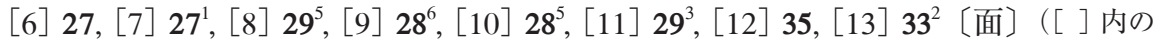
数字は卷次を表す) の如く ${ }^{11)}$ ，すなわち始めの 5 巻迄は第 3 巻を暫くおけばいずれ も22〜24面程度 ${ }^{12)}$ なのが第6巻以降は 27 面以上に急増し，のみならず巻を追う 毎に増大して最多の場合は最少のそれの約 1.6 倍の 35 面にも達するという様相を 見せ,このようなことはもしこれが最初からのものとすれば極めて異様と言うか 不自然で不可解で, ということは換言すればこのカンギュル所収本は後に改変さ れてかくなった——すなわち，その改変というのは筆者の考えでは経末にかなり の長文を付加するというものであるが，その仕方は巻数はそのままで増えた分量 の分だけ各巻に分配・配属するというもので，その操作や作業は経末から始めて 第 6 巻迄及んだために結果的にこうなった——ものではないかということと，そ してもう一つは, これは Tib. 自身ではなくて中国でのものということになるが, 中国にはこの『法華経』の伝来に関する唐代の僧祥撰の『法華伝記』が伝える, 具体的には「今長安所伝四本不同。一五壬偈，正無畏所伝是也．二六文五百偈， 
丛法護所訳是也. 三六禾偈, 鳩摩羅什所伝是也. 四六毛文百偈, 闍那崛多所伝是 也」(「部類増減第一」, 大正 $51,49 \mathrm{~b}$. 傍点は引用者) とする伝承があって, すなわちこ こでは中国に伝えられた『法華経』には現存する竺法護訳『正法華経』などの3 本以外にそれらより千偈以上も少ない「五千偈」のもの（以下，「五千偈本」と称す ることにする）も存したとされているが13)，もしそれが事実とすればその「五千偈 本」が改められ (付加増広され) て現行本のようになったということも多分に考え られ，上述のことを少なくとも傍証する有力な資料（証拠）になるのではないか, ということである.

\section{4.「3900偈本」とは? —『法華経』の成立論と構成部分の分量から—} それでは，もしそのように現行のカンギュル本は後世の改変に依るものとすれ ば，元の “3900 ssl, 13 bp”の『法華経』（以下，「3900偈本」と呼ぶことにする）とは一 体どのようなものということになるのであろうか. それについて検討するために はTib. 訳や漢訳などの訳本を基にしたのでは種々制約があって不便であるが, 幸いこの『法華経』にはSkt. 本が存してそれに従えばそのようなことも殆ど解消 することになるので, 以下ではその Skt. 本, 特に現在最も一般的で多用されて いると思われる $K N$ と $W T$ 本を基に, 検討や考察を試みるということにしたい.

その前に, 当該の Skt. 本の全体の分量 (偈数) がどうなっているかを確認して おくことにすれば, それについては本経には偈頌が多数含まれていてその韻律の 扱い方によって結果もかなり異なってくることになるので, その計量（計数）は 偈頌と長行に分けて行うのが便宜ということになろう．そこで先ず偈頌の方から 言えば，これの偈頌に対しては幸いWTで韻律の詳しい分析や偈数の算定などが 行われているのでそれをそのまま示せばその総数は $1232 〔$ 〔偈〕になるが（WT pp. 26-35, 特に31を参照), ただこの計数では韻律の相違〔に由る音節数の違い] ${ }^{14)}$ ということは考慮されていないのでその点も含めて言えば, ここではその具体的 な計算法については省略するが，〔ś1に換算した〕総数は約 1608 〔偈〕になる（又 は, 1232偈より376偈増える）ということになろう。一方, 長行に関しては, その詳 しい計算法等は同様に省略するが，筆者の計算では約 $3791 〔$ 偈〕になるので，し たがって両者を併せた Skt. 本全体の偈数も約 5023 〔偈〕（韻律の相違を考慮した場合 は同様に376偈増えて約 5399 偈. なお, こ〔れら〕の偈数は前述した Tib. 訳のカンギュル所 収本が実際に後に付加増広されたものであることを〔間接的に〕示すものということになろ う）ということになるであろう.

このことを念頭に，本題の該 “3900 śl, 13 bp”のテキスト（以下，「3900偈本」と称 
することにする) が一体どのようなものになるのかということであるが，その問題 に関しては，実はこの『法華経』はその成立についてこれ迄様々に論じられてい て，そのような「成立論」备) が有益な示唆を与えてくれるのではないかと思われ る. そこで, ここでもそれを参考や手掛りに考察を進めるということにしてみた い.ということでその『法華経』の成立論について見ると，同説は大きく先ず経 は段階を経ず一時に成立したとする言わば「同時成立説」とそうではなく幾つか の段階を経たと見る「多段階説」の如く分けて捉えることができるであろう．そ の中，前者はここでは論外ということになるので後者についてだけ言えば，その ように解される最大の理由は本来なら巻末に置かれる筈の「嘱累品」が鳩摩羅什 訳本ではそうではない途中にあってその後更に6つの章（所謂る「後の六品」）が続 く形になっているということにあろう。そして, その上で同説は更に幾つかに細 分化されているのであるが，それはともかくここではそのような諸説の中で便宜 上最も適切な一と思われる——本田義英氏（本田1933）のものを採上げ，それ を基に考察を行うことにしたい.

その本田氏の説について初めに少し説明しておけば, 明言しているわけではな いが同氏は『法華経』の現存する 3 本の漢訳と Skt. 本及び Tib. 訳という計 5 種の 「異本」（テキスト）を基に先ず『法華経』全体を後世の付加と考えられる「後分」 とそれを除いた「原始分」に2大分し（したがって，同氏説は基本的には「2段階説」 と称してよいであろう), 前者は更に $(\mathrm{A})$ ～(G) の7つに細分する（同氏はそれらを第 1 次〜第7次〔後分〕と称している)。その中の3つは実は「後の六品」の中の「普門 品」を更に細分したものであるが, ここでは「後の六品」は分ける必要はないと 考えるので一纒めにし，そこに含まれる分量 ${ }^{16)}$ も一緒に示すことにすれば，そ の「後分」は前から順に第 1 次は「譬喻品」の偈の後半部分で45（63）偈, 第 3 次 は沜摩羅什訳本に欠けている「薬草喻品」の後半部 ${ }^{17)}$ で116偈, 第5次は「提婆 達多品」〔の対応部分〕で119（122）偈，そして第2,6,7次を併せた「後の六品」 は950（960）偈の計4つで18), また総偈数は1230（1261）〔偈〕の如くなることが知 られる.これが「後分」の全分量で, 一方「原始分」はSkt. 本の全体からその 「後分」を除いたものになるのでその分量も先に見（確認し）た Skt. 本の全分量か ら「後分」の分を引いた, 実際には約 $3793(4138)^{19)}$ 偈ということになるが, そこ でもしそうとすればこの特に“3793”なる数值（偈数）が一体何を表すのかについ ては最早改めて言う迄もないであろう.

5. 要 結 こうして筆者は『デンカルマ目録』で言われる“3900 śl, 13 bp”の 
『法華経』というのは実は本田説の「原始分」〔だけ〕のそれの謂ではないかと考 えるのであるが果して如何であろうか. 念のために付言すれば, 数值的には同説 の第 1 次後分と第 3 次後分或いは両者を併せた全偈数は順に 3838, 3909, 3954 とい ずれも前述した“3900（ś1)”の摇れの幅の3750４050〔偈〕の中に収まるので数 值的にはその中にそれ〔ら〕が含まれる可能性もあることにはなるが，しかしも し仮にそれ〔ら〕が含まれていたとしても少なくとも「後の六品」一一と, 数值 的にはともかく少なくとも経典史的には恐らく「提婆達多品」〔の対応部分〕も は除かれることになるので, それと比べればそれ程重要な問題ではないと 言ってよいであろう。いずれにしても，もし上述したことが正しかったとすれ ば，そのことは単に Tib. 訳のみならず『法華経』そのものの成立〔史〕や伝承 〔史〕などにとっても極めて重要な意味や意義を持つものということになろう． と共に, それによって新たな問題や課題なども生じてくることになるかもしれな い.ともあれ, それらの件に関しては今後に委ね, 如上のことを指摘した上で取 敢えず本稿についてはこの辺で閣筆するということにしたい.

1）これの正式のタイトルは “Pho brang stod thang ldan dkar gyi chos 'gyur ro cog gi dkar chag” で，略して“dkar chag lDan dkar ma”などと，また「デンカル」（IDan dkar）は「ヘンカル」 (lHan dkar) とも言われる。本書は西蔵大蔵経のテンギュル部に収められている（D No. 4364, P No. 5851）他に芳村修基（Yoshimura 1974）, ラルー（Lalou 1953），ヘルマン=プ ファント (Herrmann-Pfandt 2008) の3氏によって出版され, それらは細部においては一致 しない点もあるが, 基本的にはそれ程大きな違いはないと言ってよいであろう。なお, 以下, これについては『デンカルマ目録』と称することにする.

2）最初の角括弧内の数字は出版者が付した経の整理番号で原文にはない（この番号は Lalou 1953 も同じであるが, Yoshimura 1974では以後の場合も含めて1番ずつ若くなる). なお，本稿内では Tib. 文字の表記（転写）法はワイリーの方式に従い（それ以外の場合 も同方式に改める)，またここでは D を底本にし，Pに異読等がある場合はそれも一緒 に掲げておくことにする.

3）この “bp”の語に関しては，例えば Habata 2013, xxvii などを参照（ただし，そこでは同 語のインドとの関係については言及されているが, 筆者が述べたような中国の特に 「巻」と結び付けて捉え解するようなことはされてはいない).

4）記号の用法は, 最初の数字は葉の番号, 次の a と b は表面と裏面, そして最後の肩付 きの小字は行をそれぞれ表す。なお, 以下, 本稿内ではこの分量は葉の枚数ではなく面 数で表すことにする.

5）この対応経の比定はこれ迄何人かの学者によって行われているが, ここではへルマン =プファント（Herrmann-Pfandt 2008）のそれに依ることにした. また，当該の経には 『デンカルマ目録』の彼に依る番号と $\mathrm{D}, \mathrm{P}$ 両版の経番号も一緒に付したが, 経名はここ では漢訳名だけ掲げることにした（Tib. 訳名については〈参考文献〉の項を参照）.

6）計算上, 以下，ここでは行は言捨四入で繰上げて 1 面に数えることにした（他の場合 も同じ). 
7）この両経以外には, [19］『華厳経』「金剛幢迴向品」（D No. 44 [30]，364 面), [82］『大 乗大集地蔵十輪経』（D No. 239, 2834 面），そして [250］『賢愚経』（D No. 341, 339面）の3 経が存する（ここでは D の経番号と実際の分量のみを掲げ， P のそれは省略. なお，こ こに示した『デンカルマ目録』に所掲のものに関しては, カンギュル所収本との〔直接 の]対応関係ということも含めて，改めて検討する必要があるかもしれない).

8）因みに，前者の『涅槃経』に対する『日蔵経』の実際の分量の割合は $3 \%$ 以下で，前 述した $4 \%$ という範囲内に収まることになる.

9）この点については Habata 2007, 105 を参照.

10）この第3巻は第3章の「譬喻品」だけで一巻を占めてその分量もそのまま示せば 29 面 ということになるが, 後述するように第3章の特に最後の部分は後世の付加と考えられ ているものなので，参考迄にこの巻については本来のと後世の付加と考えられるものの 2つに分けた部分の分量も（括弧内に，前者はイタリック体にして）一緒に掲げておく ことにした（次の注11）の場合も同じ).

11）因みに，Pでは次のようになっている。 [1] 26, [2] 27 $7^{3},[3] 33^{6}\left(29^{1}+4^{7}\right)$, [4] $26^{4}$,

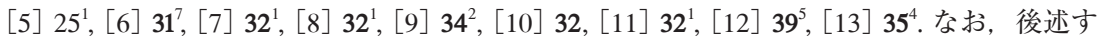
るように第 3 巻（これについては前注 10）も併せ参照）と第 5 巻より後の各巻はそれ以 外の巻に比べて分量がかなり多くなっているが, ここではそのことを見易くするために 太字で表しておくことにする（上のPに関しても同様）.

12）因みに, 第 5 巻迄の分量を平均してそれを 13 倍すると, Dの分量は〔 $(23+24+$ 29 [25] +23+22) $\div 5 \times 13=314.6$ [304.2] から] 約 315 [304] 面ということになって, 『涅 槃経』のそれにかなり近いものになることが知られる（[ ] 内は前注 10）で指摘した, 「譬喻品」で本来のものとされる部分の分量〔と, それを用いて計算した場合の值〕を表 す．またPについてはここでは省略).

13）この『法華伝記』の「五千偈本」の記事については芳村 1970, 255 でも触れられてい る。なお，この「五千偈本」(又はそれに相当すると考えられるもの）に関しては，『法 華伝記』の別の箇所では正無畏以外にも『正法華経』を訳した西晋の竺法護と東晋の支 道林の 2 人によって, 計 3 度漢訳されたとされている（「伝訳年代第三」の項，大正 51 , $50 \mathrm{c}$ を参照)。また，この「五千偈本」に関しては，ここでは詳しい説明等は省略する が，筆者は，それの「五千」は実は“3900”などの誤り一一計数違い＝数え過ぎ—で, つまり『デンカルマ目録』の言う“3900 śl, 13 bp”のそれと同じものを表しているのでは ないかと考えているので，そのことも付加えておきたい.

14）例えば triștubh-jagatī について言えば，同韻律は 1 詩句（pāda）の音節数が 11 〔音〕の triștubh と 12 〔音〕の jagatīの入混じったものであるが, śloka はそれが8〔音〕なので, 後者の 1 偈は前者の triștubh なら 1.375 偈, また jagatī とすれば 1.5 偈にそれぞれ当ること になる（実際には，WTでは triștubh-jagatī の偈は914偈とされているが, triștubh と jagatī の比は筆者の算定では約 $4: 1$ なのでそれを考慮した 1 詩句当りの音節数は約 11.2 〔音〕 になって，したがって同韻律の 914偈は〔 $11.2 \div 8 \times 914=1279.6$ から〕 ślokaの約 1280 偈 になる〔それに相当する〕ということになる）。

15）この件については例えば佐々木 1968 や伊藤 2007 などを参照.

16）算出法は前述した偈頌と長行のそれに準じる，なお，括弧内は韻律の違いを考慮した 場合のものを表す.

17）この沜摩羅什訳に欠けている「薬草喻品」の後半部に関しては, 原本にはあったが敢 えて訳されなかったとする意見も存するが，本質に関わる問題ではないのでここでは触 れないことにする.

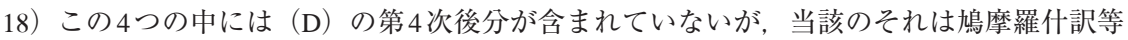


にはなく竺法護訳だけに存するものということになる.

19）この韻律の違いを考慮した場合の総偈数は “3900（śl）”の摇れ（許容範囲）の上限の 4050 をなり大きく超えることになるので, ここ(『デンカルマ目録』) ではその問題は 実際には殆ど〔全く?!〕顧慮され〔てい〕なかったと考えてよいであろう。

〈略号表〉（本文中に示したものと下記以外は〈参考文献〉の当該の項目末の括弧内に示す） Tib. = Tibet/Tibetan; 大正 [蔵〕 $=$ 大正新脩大蔵経.

\section{〈参考文献〉}

Pho brang stod thang ldan dkar gyi chos' gyur ro cog gi dkar chag. D No. 4364, P No. 5851.

Dam pa'i chos pad ma dkar po zhes bya ba theg pa chen po'i mdo. D No. 113, P No. 781.

'Phags pa yongs su mya ngan las'das pa chen po’i mdo (『涅槃経』). D No. 120, P No. 788.

'Phags pa zhin tu rgyas pa chen po'i sde nyi ma'i snying po zhes bya ba’i mdo (『日蔵経』). D No. 257,

P No. 923.

Herrmann-Pfandt, Adelheid. 2008. Die lHan kar ma: Ein Früher Katalog der ins Tibetische Übersetzten Buddhistischen Texte. Philosophisch-Historische Klasse Denkschriften 367. Wien: Österreichische Akademie der Wissenschaften.

Lalou, Marcelle. 1953. "Contribution à la Bibliographie du Kanjur et du Tanjur: Les Textes Bouddhiques au Tempts du Roi Khri-sron-lde-bcan.” Journale Asiatique 241: 313-353.

Yoshimura, Shuki. (1950) 1974. "The Denkar-Ma, An Oldest Catalogue of the Tibetan Buddhist Canons.”『インド大乗仏教思想研究——カマラシーラの思想——百華苑 99-199.

Kern, Hendrick and Nanjio, Bunyiu. 1976. Saddharmapundarīka. Bibliotheca Buddhica X. Osnabrück: Biblio Verlag $(=K N)$.

Wogihara, Unrai and Tsuchida, C. 1934-1935. Saddharmapundarīka-sūtram, Romanized and Revised Text of the Bibliotheca Buddhica Publication by Consulting a Skt. MS. \& Tibetan and Chinese Translations. Tokyo: The Seigo-Kenkyūkai $(=W T)$.

Habata, Hiromi. 2007. Die Zentralasiatischen Sanskrit-Fragmente des Mahāparinirvāna-Mahāsūtra: Kritische Ausgabe des Sanskrittextes und seiner Tibetischen Übertragung im Vergleich mit den Chinesischen Übersetzungen. Indica et Tibetica 51. Marburg: Indica et Tibetica Verlag.

. 2013. A Critical Edition of the Tibetan Translation of the Mahāparinirvāna-Mahāsūtra. Contributions to Tibetan Studies 10. Wiesbaden: Dr. Ludwig Reichert.

僧詳『法華伝記』. 大正 No. 2068 (大正蔵第 51 巻所収).

伊藤瑞颚 2007『法華経成立論史一一法華経成立の基礎的研究——平楽寺書店.

佐々木孝憲 1968 「法華経成立論の展開」望月歓厚編『近代日本の法華仏教』法華経研究 II, 平楽寺書店, 563-586.

本田義英 1933「後分法華経に於ける二三の問題」『日本仏教学協会年報』4: 188-196.

芳村修基 1970「正法白蓮華経のチベット語訳とその展開」金倉圓照編『法華経の成立と 展開』法華経研究 III, 平楽寺書店, 251-271.

〈キーワード〉 ティベット訳『法華経』,『デンカルマ目録』, 3900偈本『法華経』, 『法華 経』の〕「原始分」, テキストの改変, dkar chag lDan/lHan dkar ma.

(創価大学名誉教授) 